\title{
Analisa Perbandingan Kualitas Pelayanan Web E-Commerce Terhadap Kepuasan Konsumen Menggunakan WebQual 4.0
}

\author{
Angga Hernawan ${ }^{1}$, Rachman Komarudin ${ }^{2}$, Nurul Afni ${ }^{3}$ \\ ${ }^{1,2}$ Sistem Informasi Sekolah Tinggi Manajemen Informatika dan Komputer Nusa Mandiri \\ ${ }^{3}$ Sistem Informasi Universitas Bina Sarana Informatika \\ ${ }^{1}$ anggahernawan@gmail.com, ${ }^{2}$ rachman.rck@ nusamandiri.ac.id, ${ }^{3}$ nurul.nrf@bsi.ac.id
}

\begin{abstract}
ABSTRAK. E-commerce adalah perpaduan antara proses bisnis dengan teknologi informasi dimana pebisnis dengan pelanggan melakukan sebuah transaksi elektronik secara online. Faktor pendukung e-commerce salah satunya adalah website. Saat ini banyaknya masyarakat yang berbelanja online atau bisa di sebut e-commerce yang ada di Indonesia seperti Lazada, Tokopedia dan Bukalapak. Kualitas dari website e-commerce dapat berpengaruh pada banyaknya pelanggan yang memutuskan untuk online shopping pada e-commerce tersebut, untuk mengetahui tinggi dan rendahnya kualitas suatu website di tentukan melalui Webqual 4.0. Dalam penelitian ini penulis menggunakan metode kuesioner Manual terhadap 150 responden yang menggunakan web E-commerce Tokopedia, Lazada dan Bukalapak. Kemudian dilakukan analisis terhadap data-data yang diperoleh berupa analisis deskripstif untuk untuk menganalisis profil responden penyajian data melalui tabel, analisis kuantitatif meliputi uji validitas, uji reliabilitas, uji regresi linear berganda. Dari penelitian terhadap 150 responden, hasil penelitian menunjukkan pengaruh signifikan antar variable, yaitu (1) Kegunaan terhadap Kepuasan, (2) Kualitas Informasi terhadap Kepuasan, dan (3) Kualitas Interaksi Layanan terhadap Kepuasan, hasil analisis baik dinilai baik secara parsial maupun simultan kualitas website
\end{abstract}

Kata Kunci: E-Commerce, Kualitas Web, Kepuasan, Regresi Linear Berganda

\begin{abstract}
Electronic Commerce (E-commerce) is the activity of buying or selling of products on online services or over the internet. One of the supporting factors that make E-commerce grows is the way they develop websites that make it easier for consumer to buy or sell their products. Since the quality of e-commerce websites can affect the number of customers who decide to shop through an e-commerce system. The Author decided to make a comparison between three well-known E-commerce website such as Tokopedia, Bukalapak, Lazada through WebQual 4.0. In this research, the author uses an manually survey method to 150 respondents who use the three well known E-commerce websites above. The data obtained from the survey were analyzed using descriptive methods, quantitative methods, validity test, reliability test, and multiple linear regression tests. and the results are presented in a table format. The result of the survey to 150 respondents showed three significant influences between variables such as (1) In use satisfaction, (2) Information on quality satisfaction, and (3) Quality of Service Interaction, the results of the analysis were based on both partial or simultaneous website quality.
\end{abstract}

Keywords: E-Commerce, Web Quality, Satisfaction, Multiple Linear Regression

\section{PENDAHULUAN}

Kemajuan teknologi adalah sesuatu yang tidak bisa dihindari dikarenakan seiring dengan berjalannya kemajuan ilmu pengetahuan membuat kemajuan teknologi itu muncul secara beriringan. Suatu Negara dikatakan maju jika memiliki tingkat penguasaan teknologi tinggi (high technology). Kemajuan teknologi yang sangat pesat dan terus berkembang saat ini membuat persaingan bisnis didunia situs online menjadi begitu ketat.

Disisi lain pengguna menghadapi masalah seperti kepercayaan keamanan dan biaya yang sangat tinggi dalam membuka sebuah usaha online. Istilah e-comemerce biasa digunakan dalam kegiatan transaksi secara online. Perkembangan e-commerce semakin pesat ditandai dengan semakin meningkatnya pengguna internet di indonesia. Berdasarkan survey MarkPlus Insight pengguna internet di Indonesia pada tahun 2012 mencapai 61,08 juta orang.

E-commerce adalah perpaduan antara proses bisnis dengan teknologi informasi dimana pebisnis dengan pelanggan melakukan sebuah transaksi elektronik secara online. Prilaku pada pelanggan e-commerce memang sedikit berbeda dengan prilaku konsumen tradisional, Bagi konsumen online melakukan transaksi dengan pemasar online akan mempertimbangkan ketidak pastian dan resiko jika dibandingkan dengan transaksi jual beli secara tradisional menurut (Furkonudin, Emi Suryadi, 2016)

Faktor pendukung e-commerce salah satunya adalah website. Konsumen pada e-commerce berinteraksi dengan perusahaan menggunakan website menurut (Fauziah, 2018). Saat ini banyak nya 
masyarakat yang berbelanja online atau bisa di sebut e-commerce yang ada di indonesia, tentunya tiap website e-commerce memiliki kelebihan dan kekurangannya, seperti Lazada, Tokopedia dan Bukalapak.

Kualitas dari website e-commerce dapat berpengaruh pada banyaknya pelanggan yang memutuskan untuk online shopping pada e-commerce tersebut, untuk mengetahui tinggi dan rendahnya kualitas suatu website di tentukan ada sebuah standart. Adapun instrument-instrument penelitian yang di gunakan dalamWebQual 4.0 adalah usability, information quality, service interaction, dan kepuasan pelanggan Menurut(Agustina, 2016).

\section{METODE}

\section{A. Metode Webqual}

WebQual merupakan suatu pengukuran untuk mengukur kualitas dari sebuah website berdasarkan instumen-instrumen penelitian yang dapat dikategorikan ke dalam 4 variable yaitu Usability, Information Quality, Service intercation Quality, Overall impression kesemuanya adalah pengukur konsumen atau user terhadap kualitas dari website tersebut, menurut wyckof dalam (Tjiptomo, 2014) kualitas jasa tingkat keunggulan ( exceliance) yang diharapkan dan pengendalian ( keungulan tersebut untuk memenuhi keinginan pelanggan ) kesemuanya adalah pengukur kepuasan konsumen atau user terhadadap kualitas dari website tersebut.

WebQual sudah mulai dikembangkan sejak tahun 1998 dan telah mengalami beberapa interaksi dalam penyusunan dimenensi dan butir pertanyaan yaitu WebQual 4.0 (Nada, \& Wibowo, n.d. 2015).

Disusun berdasarkan 4 dimensi yaitu Usability, Information Quality, Service intercation Quality, Overall impressionseperti dapat dilihat pada Tabel:

Tabel 1. Indikator Webqual 4.0

\begin{tabular}{|c|c|}
\hline Dimensi & Webqual 4.0 Item \\
\hline Usability & $\begin{array}{ll}\text { 1. } & \text { Kemudahan untuk dioperasikan. } \\
\text { 2. } & \text { Interaksi dengan website jelas dan dapat dimengerti. } \\
\text { 3. } & \text { Kemudahan untuk navigasi. } \\
\text { 4. } & \text { Kemudahan menemukan alamat website. } \\
\text { 5. } & \text { Tampilan yang atraktif. } \\
\text { 6. } & \text { Tepat dalam penyusunan tata letak informasi. } \\
\text { 7. } & \text { Tampilan sesuai dengan jenis website pemerintahan. } \\
\text { 8. } & \text { Adanya penambahan pengetahuan dari informasi website. }\end{array}$ \\
\hline $\begin{array}{l}\text { Information } \\
\text { Quality }\end{array}$ & $\begin{array}{l}\text { 9. Menyediakan infomasi yang cukup jelas. } \\
\text { 10. Menyediakan informasi yang dapat dipercaya. } \\
\text { 11. Menyediakan informasi yang up to date. } \\
\text { 12. Menyediakan informasi yang relevan. } \\
\text { 13. Menyediakan informasi yang mudah dibaca dan dipahami. } \\
\text { 14. Menyediakan informasi yang cukup detail. } \\
\text { 15. Menyajikan informasi dalam format yang sesuai. }\end{array}$ \\
\hline $\begin{array}{l}\text { Service } \\
\text { intercation } \\
\text { Quality, }\end{array}$ & $\begin{array}{l}\text { 16. Mempunyai reputasi yang baik. } \\
\text { 17. Mendapatkan keamanan untuk melengkapi transaksi. } \\
\text { 18. Rasa aman dalam menyampaikan data pribadi. } \\
\text { 19. Kemudahan untuk menarik minat dan perhatian. } \\
\text { 20. Adanya suasana komunitas. } \\
\text { 21. Kemudahan untuk memberikan masukan (feedback). } \\
\text { 22. Tingkat kepercayaan yang tinggi atas informasi yang } \\
\text { disampaikan website. }\end{array}$ \\
\hline $\begin{array}{l}\text { Overall } \\
\text { impressionseperti }\end{array}$ & 23. Pendapat secara umum tentang website ini. \\
\hline
\end{tabular}

Sumber : (irawan, 2012) 


\section{B. Skala Likert}

Skala Likert menurut (Sugiyono, 2009)) digunakan untuk mengukur sikap, pendapat, dan persepsi seseorang atau sekelompok orang tentang fenomena sosial. Untuk keperluan analisis kuantitatif, maka jawaban itu dapat diberi skor, misalnya : Sangat setuju diberi nilai 5, setuju nilai 4, cukup setuju nilai 3, tidak setuju nilai 2 dan sangat tidak setuju diberi nilai 1.

\section{Rancangan Penelitian}

Rancangan penelitian penulis mempunyai 4 tahap yaitu:

1. Tahapan Penelitian yang terdiri dari identifikasi masalah, tujuan penelitian, dan landasan teori

2. Tahapan Pengumpulan data terdiri dari observasi, wawancara, studi pustaka, dan pembuatan kuesioner

3. Tahapan Pengolahan data terdiri dari Analisis Deskriptif yaitu menguji validasi dan reabilitas dan menguji regresi linear berganda.

4. Tahapan Analisa Data

\section{Sumber Data}

Data primer dan data sekunder digunakan pada penelitian ini. Menurut (Nugroho \& Sari, 2016) merupakan data yang diperoleh dari responden melalui kuisioner atau jug a data hasil wawancara penelitian dengan narasumber yang telah menggunakan atau mengunjugi Web E-commerce seperti Lazada, Tokopedia dan Bukalapak. Data primer diperoleh dari kuisioner yang dibagikan kepada responden yang berada di Jakarta selatan yaitu pengguna e-commerce seperti Lazada, Tokopedia dan Bukalapak. Sedangkan untuk data sekunder didapat dari catatan, buku dan majalah berupa laporan keuangan publikasi perusahaan, laporan pemerintah, artikel, buku-buku sebagai teori, majalah dan lain sebagainya.

\section{E. Teknik Pengumpulan Data}

Teknik Pengumpulan Data dalam metode ini ada 4 tahap yaitu:

1. Observasi yaitu pengamatan secara langsung dengan mengamati object penelitian dari jumlah individu dalam jangka waktu yang bersamaan. Untuk mendapatkan data yang diperlukan penulis melakukan observasi terhadap konsumen di Jakarta Selatan.

2. Wawancara digunakan untuk mendapatkan informasi dan secara lisan pembentukan responden untuk berkomunikasi tatap muka dalam kegiatan ini penulis mewawancarai konsumen atau pelanggan secara langsung.

3. Studi Pustaka ini bertujuan untuk mengumpulkan data-data dari buku-buku, internet dan jurnal yang relevan dengan penulis penelitian ini.

4. Pembuatan kuesioner adalah suatu cara pengumpulan data, dengan menyebarkan pertanyaan kepada responden, yang disusun secara tertulis kuesioner bertujuan untuk memperoleh data berupa jawaban - jawaban para responden.

\section{F. Analisis Data}

Tahapan analisis data yaitu:

1. Tabulasi Data

Kuesioner yang terisi lengkap saja yang dipergunakan, data yang sudah diseleksi diberi kode sesuai dengan variabel dan klasifikasi variabel, dan selanjutnya ditabulasi menggunakan perangkat lunak Microsoft Excel 2007.

2. Tahap Analisa Data

Untuk tahap analisa data menggunakan analisis regresi linear berganda. Sebelum itu perlu dilakukan uji validitas dan reliabilitas terlebih dahulu yang selanjutnya di lakukan proses uji normalitas data dan asumsi klasik sebagai syarat terlaksananya analisis regresi linear berganda.

A) Analisa deskriptif digunakan untuk menganalisis profil responden, penyajian data melalui tabel, grafik, diagram lingkaran. Setelah data terkumpul, proses berikutnya adalah analisis dalam bentuk kelas interval yang akan menggambarkan secara deskriptif jawaban dari responden.

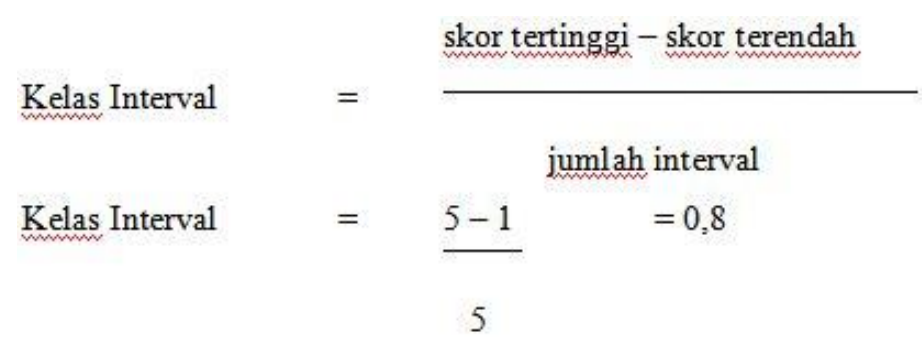


Tabel 2. Kelas Interval

\begin{tabular}{clc}
\hline No & \multicolumn{1}{c}{ Kategori } & Kisaran \\
\hline 1 & Sangat Tidak Baik & $1,00-1,80$ \\
2 & Tidak Baik & $1,81-2,61$ \\
3 & Cukup Baik & $2,62-3,42$ \\
4 & Baik & $3,43-4,23$ \\
5 & Sangat Baik & $4,24-5,00$ \\
\hline
\end{tabular}

B) Uji Validitas

Menurut Masrun yang dikutip (Sugiyono, 2003:124) mengatakan : Item yang mempunyai korelasi positif dengan kriterium (skor total) serta korelasi yang tinggi, menunjukkan item tersebut mempunyai validitas yang tinggi pula. Apabila alat ukur tersebut berada $<0,3$ (tidak valid) dan $>0,3$ (valid). Berdasarkan dari pengertian tersebut maka hal ini dilakukan untuk mengetahui pertanyaan dan pernyataan mana yang valid dan mana yang tidak valid, dengan mengkonsultasikan data tersebut dengan tingkat signifikan $r$ kritis $=0,300$ apabila alat ukur tersebut berada $<0,300$ (tidak valid). Pengujian statistik mengacu pada Kriteria :

1. $\mathrm{r}$ hitung $<\mathrm{r}$ kritis maka tidak valid

2. $r$ hitung $>r$ kritis maka valid

C) Uji Reliabilitas

Menurut (Ghozali, 2011:232), Reliabilitas adalah ukuran konsistensi internal dari indikator-indikator sebuah variabel bentukan yang menunjukkan derajat sampai dimana masing-masing indikator itu mengidikasikan sebuah variabel bentukan yang umum. Reliablitas juga merupakan salah satu indikator validitas convergent. Banyak juga yang menggunakan cronbach alpha sebagai ukuran reliabilitas walaupun kenyataannya cronbach alpha memberikan reliabilitas yang lebih rendah (under estimate) di bandingkan dengan Constuct reliability. Construct Reliability (CR) 0.70 atau lebih menunjukkan reliabilitas yang baik, sedangkan reliabilitas $0.60-0.70$ masih dapat diterima dengan syarat validitas indikator dalam model baik (Ghozali, 2011:140)

Rumus uji reliabilitas dengan teknik dari Cronbach Alpha:

$$
r_{11}=\left(\frac{k}{(k-1)}\right)\left(1-\frac{\sum \sigma t^{2}}{\sigma t^{2}}\right)
$$

Dimana :

\begin{tabular}{|c|c|}
\hline$r_{11}$ & $=$ reliabilitas instrumen \\
\hline $\mathrm{k}$ & = banyaknya butir pernyataan \\
\hline$\sum \sigma \mathrm{t}^{2}$ & $=$ jumlah varians butir \\
\hline
\end{tabular}

D) Uji Regresi

Analisis regresi linier berganda adalah hubungan secara linear antara dua atau lebih variabel independen $\left(\mathrm{X}_{1}, \mathrm{X}_{2}, \ldots \mathrm{X}_{\mathrm{n}}\right)$ dengan variabel dependen $(\mathrm{Y})$. Analisis ini untuk mengetahui arah hubungan antara variabel independen dengan variabel dependen apakah masing-masing variabel independen berhubungan positif atau negatif dan untuk memprediksi nilai dari variabel dependen apabila nilai variabel independen mengalami kenaikan atau penurunan. Data yang digunakan biasanya berskala interval atau rasio.

Persamaan regresi linear berganda sebagai berikut

$$
Y^{\prime}=a+b_{1} X_{1}+b_{2} X_{2}+\ldots . .+b_{n} X_{n}
$$

Keterangan:

$\mathrm{Y}^{\prime} \quad=$ Variabel dependen (nilai yang diprediksikan)

$\mathrm{X}_{1}$ dan $\mathrm{X}_{2}=$ Variabel independen

a $\quad=$ Konstanta (nilai $Y^{\prime}$ apabila $X_{1}, X_{2} \ldots \ldots X_{n}=0$ )

$\mathrm{b} \quad=$ Koefisien regresi (nilai peningkatan ataupun penurunan)

\section{Uji Asumsi}


Dalam melakukan analisis regresi dilakukan pula uji asumsi klasik yang terdiri dari Multikolinearitas, Heteroskedastisitas, dan Autokorelasi. Selain itu pastinya diuji pula Normalitas Data sebagai syarat dalam melakukan analisis regresi.

a. Uji Normalitas Data digunakan untuk mengetahui apakah data terdistribusi dengan normal atau tidak.

b. Uji Multikolinearitas keadaan dimana antara dua variabel independen atau lebih pada model regresi terjadi hubungan linear yang sempurna atau mendekati sempurna.

c. Uji Heteroskedastisitas metode Spearman's rho yaitu dengan mengkorelasikan nilai residual hasil regresi dengan masing - masing variabel independen.

d. Metode Uji Linearitas merupakan bentuk hubungan antara variabel independen dan variabel dependen adalah linier. Untuk mengetahui apakah variabel independen dan variabel dependen menunjukan hubungan yang linier atau tidak bisa dilakukan dengan cara membandingkan nilai signifikansi Linearity dengan signifikansi yang di tetapkan yaitu 0,05 .

1)Bila sig.linearity $<0,05 \mathrm{Maka}_{0}$ diterima, yang berarti regresi liniear.

2)Bila sig. Linearity $\geq 0,05 \mathrm{Maka}_{1}$ ditolak, yang berarti regresi tidak linear.

\section{HASIL DAN PEMBAHASAN}

1. Analisis Deskriptif Responden

Analisis deskriptif responden dilakukan dengan mengelompokkan berdasarkan jenis kelamin, usia, pendidikan terakhir, pekerjaan dan lama berbelanja online. Sementara itu, analisis deskriptif variabel dilakukan berdasarkan nilai rata-rata (mean) dari masing-masing indikator yang mewakili variabelvariabel yang diukur.

\section{Analisis Statistik Deskriptif Variabel Penelitian}

Deskriptif statistik variabel utama penelitian menggambarkan hasil penyebaran instrument penelitian yang telah dilakukan terhadap 150 responden yang terdiri dari 50 responden Tokopedia, 50 responden Lazada dan 50 responden Bukalapak. Variabel utama penelitian terdiri dari 4 variabel yaitu kegunaan, kualitas informasi, kualitas interaksi layananan dan kepuasan pelanggan.

\section{Hasil Intrumen Penelitian}

1. Uji Validitas Instrument

Uji validitas dilakukan dengan membandingkan antara $r$ hitung (Corrected Item Total Correlation) dengan $r$ tabel Apabila $r$ hitung > $r$ tabel dan bernilai positif maka kuesioner tersebut dianggap valid atau sah. Dalam penelitian ini diperoleh $\mathrm{r}$ tabel sebesar 0,1603 dengan $\mathrm{df}=\mathrm{n}-2$ dalam hal ini jumlah sampel (n) sebesar 150-2 = 148 maka di dapat $r$ tabel sebesar 0,1603 (dengan melihat $r$ tabel uji dua sisi).

Tabel 3. Uji Validitas

\section{Item-Total Statistics}

\begin{tabular}{|l|l|l|l|l|l|}
\hline & Scale Mean if & Scale Variance & Total & Multiple & Alpha if Item \\
Item Deleted & if Item Deleted & Correlation & Correlation & Deleted \\
\hline
\end{tabular}




\begin{tabular}{|l|l|l|l|l|l|}
\hline X1.1 & 100.13 & 302.573 & .484 & .395 & .907 \\
X1.2 & 100.21 & 303.753 & .443 & .409 & .908 \\
X1.3 & 100.49 & 303.527 & .393 & .356 & .909 \\
X1.4 & 100.30 & 302.507 & .448 & .388 & .908 \\
X1.5 & 100.03 & 303.436 & .478 & .447 & .907 \\
X1.6 & 99.92 & 302.611 & .508 & .496 & .907 \\
X1.7 & 100.01 & 301.067 & .591 & .599 & .906 \\
\hline
\end{tabular}

Kualitas Informasi (X2)

\begin{tabular}{|l|l|l|l|l|l|}
$\mathrm{X} 2.1$ & 99.87 & 303.083 & .600 & .574 & .906 \\
$\mathrm{X} 2.2$ & 100.14 & 299.114 & .599 & .473 & .905 \\
$\mathrm{X} 2.3$ & 100.23 & 301.576 & .541 & .446 & .906 \\
$\mathrm{X} 2.4$ & 100.33 & 302.022 & .498 & .378 & .907 \\
$\mathrm{X} 2.5$ & 100.10 & 304.493 & .471 & .426 & .907 \\
$\mathrm{X} 2.6$ & 100.28 & 302.471 & .508 & .372 & .907 \\
$\mathrm{X} 2.7$ & 100.13 & 299.346 & .581 & .499 & .906
\end{tabular}

Kualitas Interaksi Layanan (X3)

\begin{tabular}{|l|l|l|l|l|l|}
$\mathrm{X} 3.1$ & 100.16 & 301.075 & .530 & .422 & .906 \\
$\mathrm{X} 3.2$ & 100.16 & 301.048 & .536 & .405 & .906 \\
$\mathrm{X} 3.3$ & 100.22 & 304.200 & .446 & .410 & .908 \\
$\mathrm{X} 3.4$ & 100.14 & 307.799 & .348 & .340 & .910 \\
$\mathrm{X} 3.5$ & 100.15 & 309.280 & .323 & .249 & .910 \\
$\mathrm{X} 3.6$ & 100.25 & 304.805 & .463 & .353 & .908 \\
$\mathrm{X} 3.7$ & 100.33 & 306.626 & .419 & .377 & .908
\end{tabular}

Kepuassan Pelanggan (Yl)

\begin{tabular}{|l|l|l|l|l|l|} 
Y1.1 & 100.35 & 297.154 & .565 & .462 & .906 \\
Y1.2 & 100.44 & 298.973 & .542 & .473 & .906 \\
Y1.3 & 100.27 & 299.056 & .536 & .424 & .906 \\
Y1.4 & 100.15 & 299.849 & .465 & .348 & .908 \\
Y1.5 & 100.15 & 302.045 & .440 & .373 & .908 \\
Y1.6 & 100.11 & 307.411 & .386 & .338 & .909 \\
Y1.7 & 100.26 & 292.999 & .692 & .575 & .903 \\
\hline
\end{tabular}


Berdasarkan Tabel 3 menunjukkan bahwa semua indikator yang digunakan dalam penelitian ini memiliki r hitung lebih besar dari tabel $(0,1603)$ maka dapat disimpulkan semua pertanyaan dapat dikatakan valid untuk digunakan sebagai alat ukur variabel.

\section{Uji Reabilitas Isntrumen}

Uji reliabilitas digunakan untuk mengukur kuesioner yang merupakan indikator variabel. Kuesioner dikatakan reliable atau handal jika masing-masing pertanyaan dijawab responden secara konsisten atau stabil dari waktu ke waktu

Tabel 4. Uji Realibilitas

\begin{tabular}{|r|c|r|}
\hline \multicolumn{3}{|c|}{ Reliability Statistics } \\
\hline & Cronbach's & \\
& Alpha Based on & \\
& Standardized & \\
Cronbach's Alpha & Items & N of Items \\
\hline .910 & .911 & 28 \\
\hline
\end{tabular}

Dari hasil Tabel 4 diatas didapat Cronbach Alpha lebih dari 0,60 maka dapat dikatakan semua variabel dari kuesioner adalah reliable yang berarti bahwa kuesioner yang digunakan dalam penelitian ini merupakan kuesioner yang handal.

\section{Uji Normalitas}

Uji normalitas bertujuan untuk mengetahui apakah dalam model regresi, variabel terikat dan variabel bebas memiliki distribusi normal atau tidak
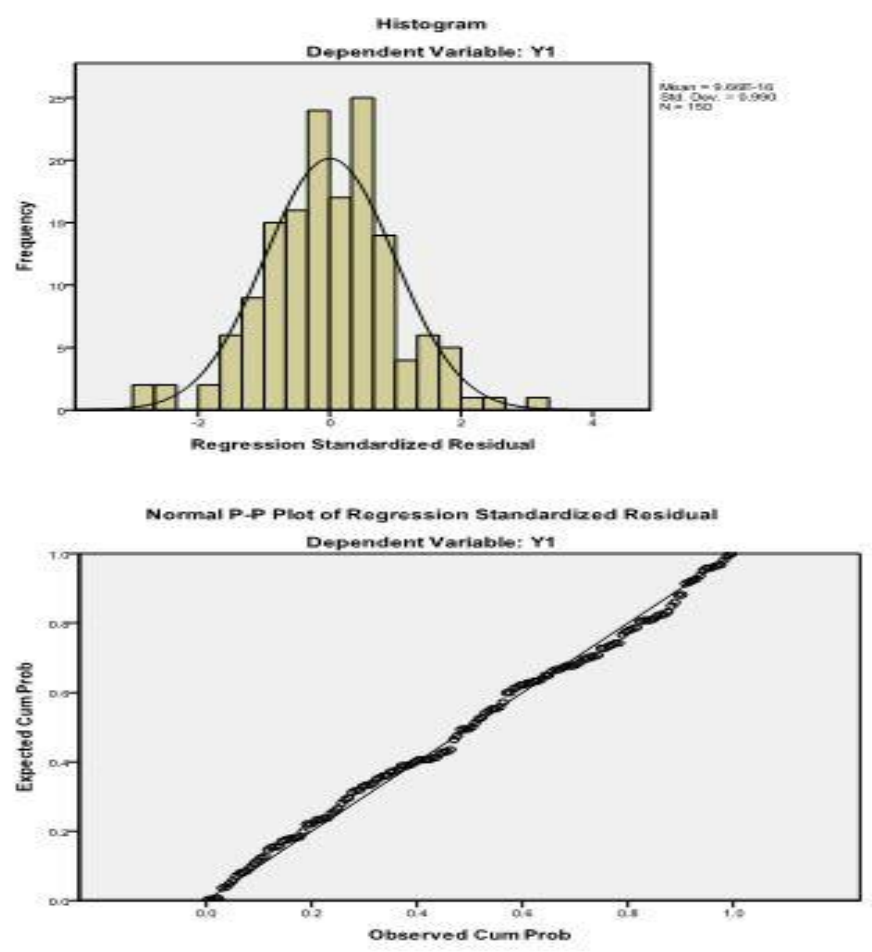

Gambar 1. Histogram Uji Normalitas Regresi Linear Berganda

Berdasarkan Gambar 1 menunjukan bahwa diagram Histogram diatas membentuk lengkung kurve normal maka residual dinyatakan normal dan asumsi normalitas terpenuhi. Dan untuk Normal P-P Plot dinyatakan memenuhi asumsi normalitas karna diagram tersebut memunjukan plot-plot mengikuti alur garis lurus. 
4. Uji Multikolineraritas

Uji multikolinearitas bertujuan untuk menguji apakah model regresi ditemukan adanya korelasi antar variabel bebas (Independent)

Tabel 5. Uji Multikolinearitas

\begin{tabular}{|l|r|r|}
\hline \multirow{2}{*}{} & \multicolumn{2}{|c|}{$\begin{array}{c}\text { Collinearity } \\
\text { Statistics }\end{array}$} \\
\cline { 2 - 4 } Model & Tolerance & VIF \\
\hline $1 \quad$ (Constant) & & \\
Kegunaan & .575 & 1.738 \\
\hline Kualitas Informasi & .386 & 2.589 \\
Kualitas Interkasi & .492 & 2.032 \\
Layanan & & \\
\hline
\end{tabular}

Berdasarkan tabel 5 menunjukkan bahwa nilai Tolerance ketiga variabel independen lebih besar dari 0,10 dan nilai VIF kurang dari 10, maka dapat disimpulkan bahwa tidak terjadi multikolinieritas.

\section{Uji Heteroskedatilitas}

Uji heteroskedastisitas adalah untuk mengetahui apakah dalam sebuah metode regresi terjadi ketidaksamaan varians pada residual (error) dari satu pengamatan ke pengamatan yang lain.

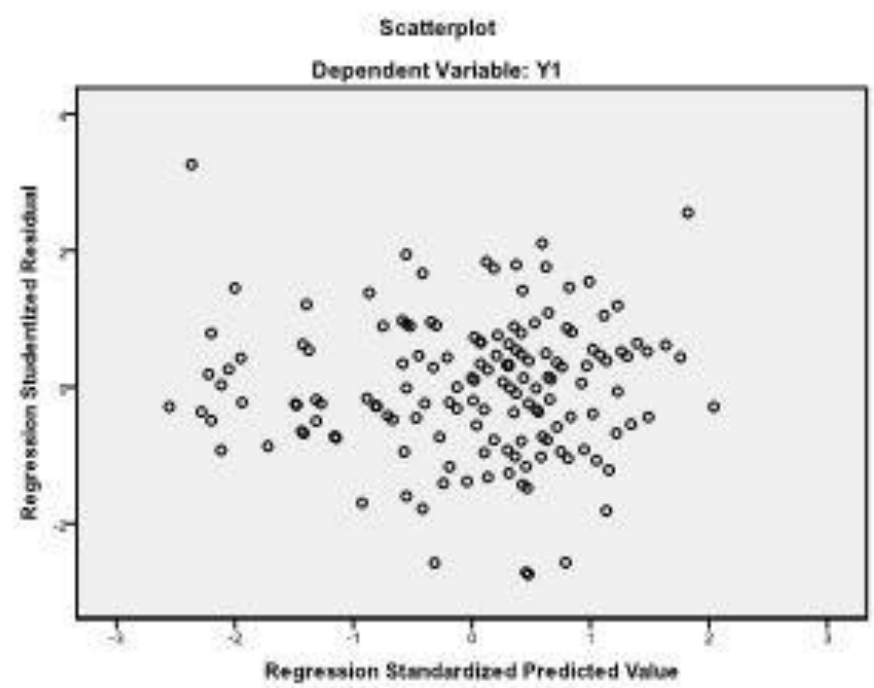

Dari gambar, dapat dilihat titik-titik menyebar di atas dan di bawah angka nol pada sumbu Y, maka tidak terjadi heteroskedastisitas. 
6. Uji Regresi Liner Berganda

Analisis ini digunakan untuk mengetahui atau meramalkan pengaruh Kegunaan, Kualitas Informasi dan Kualitas Interaksi Layanan dapat diuraikan pada Tabel 6

Tabel 6. Uji Coefficients

\begin{tabular}{|c|c|c|c|c|c|c|}
\hline \multicolumn{7}{|c|}{ Coefficients ${ }^{\mathrm{a}}$} \\
\hline \multicolumn{2}{|c|}{ Model } & \multicolumn{2}{|c|}{$\begin{array}{l}\text { Unstandardized } \\
\text { Coefficients }\end{array}$} & \multirow{2}{*}{\begin{tabular}{|c|} 
Standardized \\
Coefficients \\
Beta
\end{tabular}} & \multirow[b]{2}{*}{$\mathrm{t}$} & \multirow[b]{2}{*}{ Sig. } \\
\hline & & B & Std. Error & & & \\
\hline \multirow[t]{4}{*}{1} & (Constant) & $\begin{array}{r}- \\
1.774\end{array}$ & 1.609 & & -1.103 & .272 \\
\hline & Kegunaan & .429 & .066 & .407 & 6.535 & .000 \\
\hline & $\begin{array}{l}\text { Kualitas } \\
\text { Informasi }\end{array}$ & .237 & .082 & .220 & 2.897 & .004 \\
\hline & $\begin{array}{l}\text { Kualitas } \\
\text { Interaksi } \\
\text { Layanan }\end{array}$ & .381 & .079 & .326 & 4.847 & .000 \\
\hline
\end{tabular}

a. Dependent Variable: Kepuasan Pelanggan

Dengan melihat Tabel 6 diatas maka diperoleh persamaan regresi sebagai berikut :

$\mathrm{Y}=-1,774+0,429 \mathrm{X}_{1}+0,237 \mathrm{X}_{2}+0,381 \mathrm{X}_{3}$

Dimana :

$\mathrm{Y}=$ Kepuasan Pelanggan

$\mathrm{a}=$ Konstanta

$\mathrm{X}_{1}=$ Kegunaan

$\mathrm{X}_{2}=$ Kualitas Informasi

$\mathrm{X}_{3}=$ Kualitas Interaksi Layanan

Adapun penjelasan hasil persamaan analisis regresi linier berganda sebagai berikut:

- Konstanta sebesar -1,774 menunjukan bahwa apabila Kegunaan, Kualitas Informasi dan Kualitas Interaksi Layanan tidak memberikan pengaruh maka cumulative abnormal return akan bernilai sebesar -1,774, dimana negatif disini menunjukkan cara untuk menurunkan laba.

- Koefisien regresi Kegunaan $\left(\mathrm{X}_{1}\right)$ sebesar 0,429 artinya Kegunaan meningkat satu satuan maka Kepuasaan Pelanggan mengalami kenaikan sebesar 0,429 satuan dengan asumsi variabel independen lainnya bernilai tetap.

- Kualitas Informasi $\left(\mathrm{X}_{2}\right)$ sebesar 0,237 artinya Kualitas Informasi meningkat satu satuan maka Kepuasan Pelanggan akan mengalami kenaikan sebesar 0,237 satuan dengan asumsi variabel independen lainnya bernilai tetap.

- Kualitas Interaksi Layanan $\left(\mathrm{X}_{3}\right)$ sebesar 0,381 artinya Kualitas Interaksi Layanan meningkat satu satuan maka Kepuasan Pelanggan akan mengalami kenaikan sebesar 0,381 satuan dengan asumsi variabel independen lainnya bernilai tetap.

a. Koefisien Determinasi

Koefisien Determinasi ( $\mathrm{R}$ square) atau disimbolkan denga R2 dimaknai sebagai sumbangan pengaruh yang diberikan variabel bebas $(\mathrm{X})$ terhadap variabel terikat $(\mathrm{Y})$. 
Tabel 7. Uji Model Summary

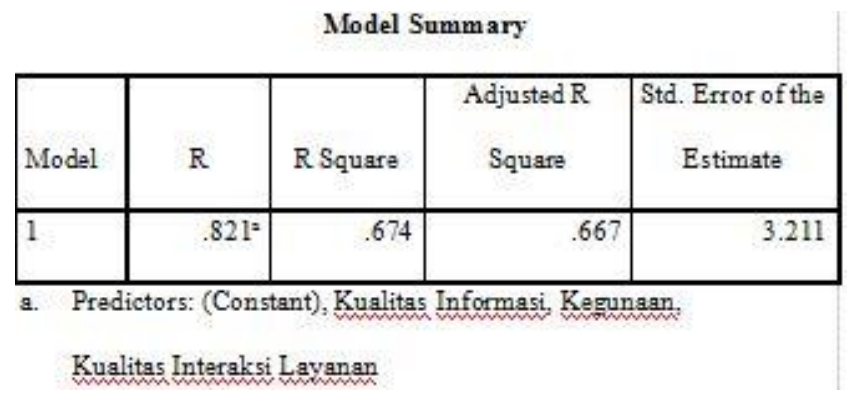

Dari output model summary, diketahui nilai koefisien determinasi (R Square) sebesar 0,674 (nilai 0,674 adalah pengkuadratan dari koefisien korelasi atau R). Besarnya angka 0,674 sama dengan 67,4\%. Angka tersebut mengandung arti bahwa kegunaan kualitas informasi dan kualitas interaksi layanan berpengaruh terhadap kepuasan pelanggan sebesar $67,4 \%$. Sedangkan sisanya $(100 \%-67,4 \%=32,6 \%)$ dipengaruhi variabel lain di luar model regresi ini.

\section{b. Uji Persial (Uji T)}

Uji ini digunakan untuk mengetahui apakah variabel independen yaitu apabila Kegunaan, Kualitas Informasi dan Kualitas Interaksi Layanan secara parsial berpengaruh secara signifikan pada variabel dependen yaitu Kepuasan Pelanggan.

Tabel 8. Uji T

\begin{tabular}{|c|c|c|c|c|c|c|}
\hline \multicolumn{7}{|c|}{ Coefficients ${ }^{2}$} \\
\hline \multicolumn{2}{|c|}{ Model } & \multicolumn{2}{|c|}{$\begin{array}{l}\text { Unstandardized } \\
\text { Coefficients }\end{array}$} & \multirow{2}{*}{$\begin{array}{c}\begin{array}{c}\text { Standardized } \\
\text { Coefficients }\end{array} \\
\text { Beta } \\
\end{array}$} & \multirow[b]{2}{*}{$\mathrm{t}$} & \multirow[b]{2}{*}{ Sig. } \\
\hline & & $\mathrm{B}$ & Std. Error & & & \\
\hline \multirow[t]{4}{*}{1} & (Constant) & -1.774 & 1.609 & & -1.103 & .272 \\
\hline & Kegunạan & .429 & .066 & .407 & 6.535 & .000 \\
\hline & Kualitas Informasi & .237 & .082 & .220 & 2.897 & .004 \\
\hline & $\begin{array}{l}\text { Kualitas Interaksi } \\
\text { Layanan }\end{array}$ & .381 & .079 & .326 & 4.847 & .000 \\
\hline
\end{tabular}

Dari hasil perhitungan yang ditunjukan Tabel 8 maka dapat dijelaskan sebagai berikut :

- Variabel Kegunaan memiliki nilai signifikan kurang dari 0,05 yaitu sebesar 0,000 artinya Kegunaan berpengaruh positif dan signifikan pada Kepuasan Pelanggan Toko Online Tokopedia, Lazada dan Bukalapak.

- Variabel Kualitas Informasi memiliki nilai signifikan kurang dari 0,05 yaitu sebesar 0,004 artinya Kualitas Informasi berpengaruh positif dan signifikan pada Kepuasan Pelanggan Toko Online Tokopedia, Lazada dan Bukalapak.

- Variabel Kualitas Interaksi Layanan memiliki nilai signifikan kurang dari 0,05 yaitu sebesar 0,000 artinya Kualitas Interaksi Layanan berpengaruh positif dan signifikan pada Kepuasan Pelanggan Toko Online Tokopedia, Lazada dan Bukalapak.

c. Uji Simultan (Uji F) 
Tabel 9. Uji F

\begin{tabular}{|c|c|c|c|c|c|c|}
\hline \multicolumn{7}{|c|}{ ANOVA } \\
\hline \multicolumn{2}{|c|}{ Model } & Sum of Squares & df & Mean Square & $\mathrm{F}$ & Sig. \\
\hline \multirow[t]{3}{*}{1} & Regression & 3115.050 & 3 & 1038.350 & 100.698 & $.000=$ \\
\hline & Residual & 1505.490 & 146 & 10.312 & & \\
\hline & Total & 4620.540 & 149 & & & \\
\hline \multicolumn{7}{|c|}{ a. Predictors: (Constant), Kegunaan, Kualitas Informasi, Kualitas Interaksi Layanan } \\
\hline
\end{tabular}

Nilai sig 0,000 < 0,05, Hal ini menunjukkan bahwa Kegunaan, Kualitas Informasi dan Kualitas Interaksi Layanan secara bersama-sama memiliki pengaruh terhadap Kepuasan Pelanggan Toko Online Lazada, Bukalapak dan Tokopedia.

\section{KESIMPULAN DAN SARAN \\ Kesimpulan}

Kesimpulan dari hasil Uji parsial menunjukkan bahwa Variabel Kegunaan, Kualitas Informasi dan Kualitas Interaksi Layanan berpengaruh positif dan signifikan terhadap Kepuasan Pelanggan Toko Online Tokopedia, Lazada dan Bukalapak. Kemudian untuk hasil Uji simultan menunjukkan bahwa Variabel Kegunaan, Kualitas Informasi dan Kualitas Interaksi Layanan secara bersama-sama memiliki pengaruh terhadap Kepuasan Pelanggan Toko Online Tokopedia, Lazada dan Bukalapak. Dari ketiga online shop dalam penelitian ini Tokopedia lah yang memiliki nilai rata-rata keseluruhan tertinggi dibandingkan dengan 2 online shop lainnya yaitu 3.84. Kemudian disusul oleh Lazada yang memiliki rata-rata 3.67 dan yang terakhir yaitu online shop Bukalapak yaitu 3.61. Dengan kata lain, pelayanan yang diberikan Tokopedia yang berbasis web sudah baik sehingga informasi yang ada di web memberikan manfaat bagi penggunanya khususnya bagi pelanggan yang sering melakukan pembelian di online shop Tokopedia.

\section{Saran}

Penelitian ini pada dasarnya adalah melihat variabel kualitas web e-commerce berpengaruh langsung terhadap kepuasan. Perlu sebaiknya untuk penelitian selanjutnya dengan menganalisis pengaruh tidak langsung dengan menambah variabel lain yang baru. Penyebaran kuesioner dengan penyebaran secara tidak langsung (online) sehingga mampu menggambarkan secara utuh tanggapan penjualan secara online menurut pelanggan ataupun pengguna. Penelitian ini dilakukan dengan memasukkan variabel layanan web e-commerce atau biasa disebut webqual. Kualitas web ini tentunya akan berdampak pada peningkatan kepuasan pelanggan yaitu dengan meningkatnya web E-commerce Tokopedia, Lazada dan Bukalapak akhirnya menjadi sarana promosi bagi penjualan online. Dengan memiliki teknologi, interaksi yang diterapkan secara baik dan benar akan menghasilkan layanan kualitas web yang baik pula sehingga menjadikan daya tarik bagi pelanggan maupun calon pembeli untuk bertransaksi di Tokopedia, Lazada dan Bukalapak dan pengelola Bukalapak.com juga akan memberikan kontribusi untuk selalu meningkatkan kualitas webnya.

\section{DAFTAR RUJUKAN}

Agustina, N. (2016). Kualitas Layanan Website E-Commerce Lazada . co . id Menggunakan Teknik Pengukuran WebQual, 1(1), 42-54.

Fauziah, D. A. N. W. (2018). Pengukuran kualitas layanan bukalapak.com terhadap kepuasan konsumen dengan metode webqual 4.0, 3(2), 173-180.

Furkonudin, Emi Suryadi, D. (2016). EVALUASI KUALITAS LAYANAN WEBSITE E-COMMERCE, 6-7

Ghozali, Imam. 2011. "Aplikasi Analisis Multivariate Dengan Program SPSS”. Semarang: Badan Penerbit Universitas Diponegoro

Nada, N. Q., \& Wibowo, S. (2015). Pengukuran Kualitas Layanan Sistem Informasi Akademik Menggunakan Metode Webqual 4.0. Jurnal Informatika Upgris, 1(2 Desember), 122-131.

Nugroho, A. K., \& Sari, P. K. (2016). ANALISIS PENGARUH KUALITAS WEBSITE TOKOPEDIA TERHADAP KEPUASAN PENGGUNA MENGGUNAKAN METODE WEBQUAL 4 . 0 THE 
EFFECT ANALYSIS OF TOKOPEDIA WEBSITE QUALITY TOWARDS USER SATISFACTION USING WEBQUAL 4 . 0 METHOD, 3(3), 2930-2937.

Sugiyono, 2009, Metode Penelitian Kuantitatif, Kualitatif dan R\&D, Bandung : Alfabeta

Sugiyono. 2013. Metode Penelitian Pendidikan Pendekatan Kuantitatif, Kualitatif, dan $R \& D$. Bandung: Alfabeta

Tehubijuluw, Florentina dan Sugiarto. 2014. Metodologi Penelitian Cara Mudah Membuat Makalah, Skripsi, Tesis, dan Disertasi. Tangerang: PT. Matana Bina Utama 